\title{
STUDY OF THE QUALITY OF THE THERMAL SPRING MOULAY YACOUBE HAMMA AND ITS IMPACT ON THE HAMMA RIVER, SIDI SLIMANE - MOROCCO
}

Aitsi Salah and Elkhachine Douae

Laboratory of Agro-Physiology, Biotechnology, Environment and Quality Department of Biology, Faculty of Sciences, Ibn Tofail University. B, P: 133, 14000, Kenitra, Morocco.

\section{Issati Touria}

Department of Geology, Faculty of Sciences, Med V University, Rabat, Morocco.

\section{El Kharrim Khadija}

Laboratory of Agro-Physiology, Biotechnology, Environment and Quality Department of Biology, Faculty of Sciences, Ibn Tofail University. B, P: 133, 14000, Kenitra, Morocco.

\section{Tayebi Mohammed}

Laboratory of Development of Geo-Resources and Land use Planning, Department of Geology, Faculty of Sciences, Ibn Tofail University, P: 133, 14000, Kenitra, Morocco.

\section{Belghyti Driss*}

Laboratory of Agro-Physiology, Biotechnology, Environment and Quality Department of Biology, Faculty of Sciences, Ibn Tofail University. B, P: 133, 14000, Kenitra, Morocco.

*Corresponding Author

\begin{abstract}
The waters of the river Hamma were collected monthly between May 2016 and April 2017, at two stations (upstream and downstream of its confluence with the waters of the thermal source Hamma Moulay Yacoube to conduct physicochemical analysis.

The descriptive analysis showed that the waters of the river are subjected to physicochemical variations important after mixing with those of the source: enrichment with mineral salts (chlorides and sulfates) and the increase of temperature, conductivity and total hardness of water.
\end{abstract}

Keywords: Source Moulay Yacoube Hamma, water, river Hamma, physico-chemical, mineral, Sidi Slimane, Morocco. 
Cite this Article: Aitsi Salah and Elkhachine Douae, Issati Touria, El Kharrim Khadija, Tayebi Mohammed and Belghyti Driss, Study of the Quality of the Thermal Spring Moulay Yacoube Hamma and its Impact on the Hamma River, Sidi Slimane - Morocco, International Journal of Civil Engineering and Technology (IJCIET), 11(2), 2020, pp.1-11 https://iaeme.com/Home/issue/IJCIET?Volume=11\&Issue=2

\section{INTRODUCTION}

The Hamma River near the Sidi Slimane city $(18 \mathrm{~km})$ is a non-permanent watercourse. It is supplied by a set of upstream freshwater sources.

The discharge of thermal waters from the Ain Hamma My Yacoube Sidi Slimane spring into the wadi could modify the quality of the latter's water. The physico-chemical characteristics of a thermal water are related to its underground course, its depth for temperature and the mineral composition of the rocks. At depth, water can also be enriched with gas $(\mathrm{CO} 2, \mathrm{H} 2 \mathrm{~S})$ depending on the nature of the rock. Thermal waters have been the subject of several scientific studies, including those of Hakam et al Duriez (Greece), Lkhdar et al, (Moulay yacoub), Zerouale et al (Eastern Morocco) and Fekraoui (Algeria). They have particular physico-chemical characteristics that may undoubtedly modify the quality of the receiving environment $[1,2,3$, and 8$]$.

In this context, our study of the water quality of the Hamma wadi discharged by the source Hamma My Yacoube Sidi Slimane spring is part of this study. A monitoring of physicochemical parameters has been started at three water points on the wadi and at the water level of these three sources. The main objective is on the one hand to study the water quality of these three sources and on the other hand to evaluate the changes in the physico-chemical quality of the wadi waters that can be attributed to direct discharges of thermal waters into the wadi waters [7].

\section{MATERIALS AND METHODS}

\subsection{Presentation of the study area}

The city of Sidi Slimane is located on the Gharb plain, in north-west Morocco, and belongs to the Rabat-Salé-Kénitra region.

The thermal spring of El Hamma-Outita emerges on the outskirts of the pre-rifain mountain range, $12 \mathrm{~km}$ from the town of Sidi Slimane, on the road that leads to Meknes, and is very close to the marabout of Sidi Moulay Yacoub, at the bottom of the N-S cluse of river El Hamma, and its coordinates are Lambert, $X=459,60, Y=392,7$ and $Z=120 \mathrm{~m}$, with a scale of $1 / 50000$ from the map of El Kansera. 


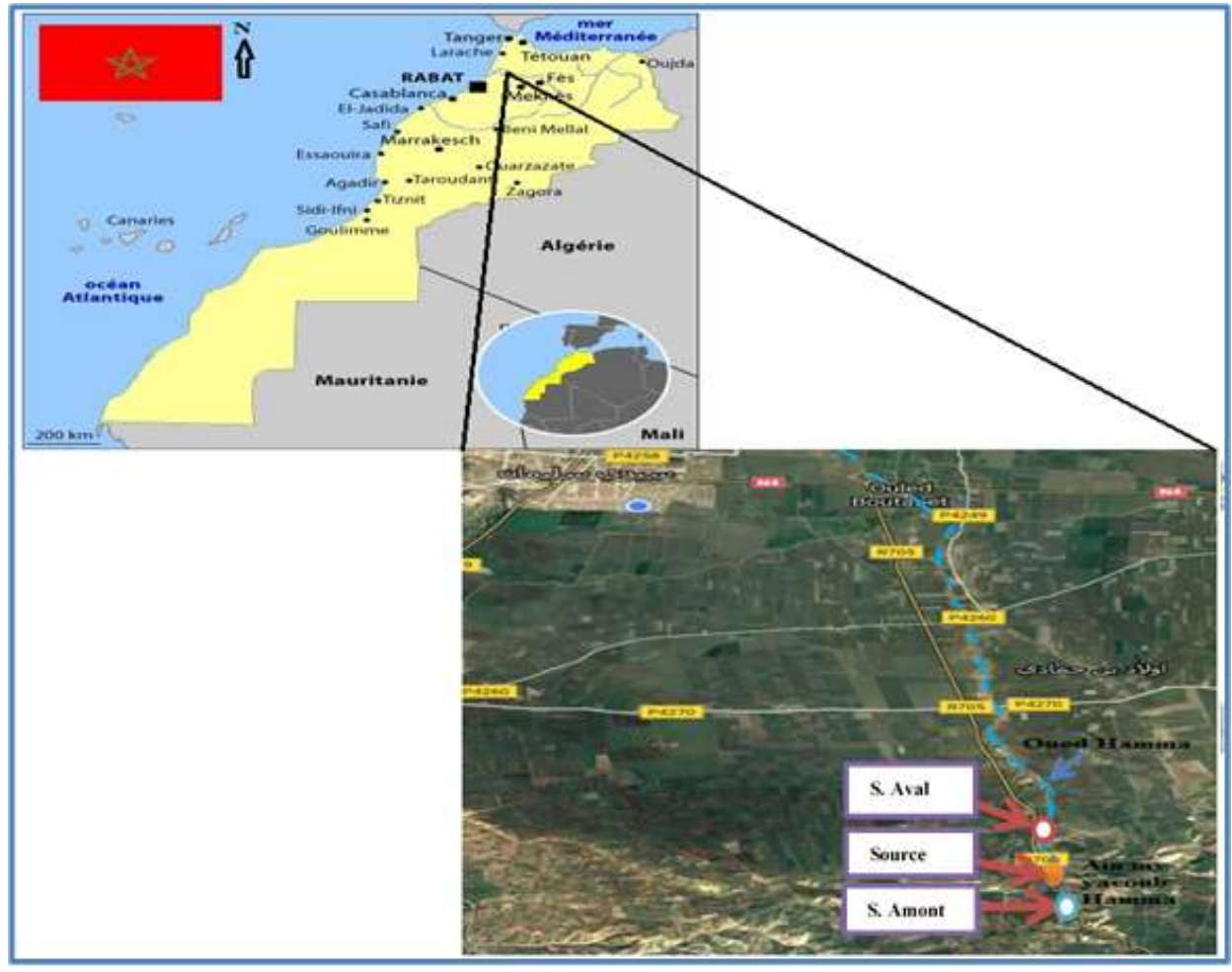

Figure 1: Geographic location of the study area.

\subsection{Sampling sites}

To assess the water quality of the wadi in the vicinity of the source, we chose two sampling sites on Hamma wadi: one site (S-amount) before $3 \mathrm{~km}$ from the confluence zone with the spring water and another site (S-aval) downstream from this zone. A third site (Source) was chosen at the water level of the Ain Hamma Outita spring.

\subsection{Sampling and Analysis}

The Water sampling was carried out during the period May 2016 to April 2017. Some parameters are measured directly in situ by portable devices: the conductivity and salinity of the water (by a portable conductivity meter of the Consort K912 type), the temperature (by a thermometer), and the hydrogen potential (by a portable $\mathrm{pH}$ meter of the Hanna Hi $8519 \mathrm{~N}$ type). The water samples are transported, in a cooler at a low temperature $\pm 4^{\circ} \mathrm{C}$, to the laboratory to analyze other major elements: Sulfates, Chlorides, TAC, Total Hardness, Calcium, Magnesium, Potassium, Sodium, Nitrates, and Dry Residue. These elements are measured in the laboratory according to approved protocols $[16,11]$.

\section{RESULTS AND DISCUSSION}

\subsection{Results}

The results of the physico-chemical analyses of the three sites studied (S-amount, Source, Saval) are presented in the form of the following tables:

\section{$\checkmark$ S-amount}


Aitsi Salah and Elkhachine Douae, Issati Touria, El Kharrim Khadija, Tayebi Mohammed and Belghyti Driss

Table 1: The physico-chemical analyses for twelve months for the S-amount site.

\begin{tabular}{|c|c|c|c|c|c|c|c|c|c|c|c|c|c|c|}
\hline Parameter. & Unit & May & June & Jul & Aug & Sep & Oct & Nov & Dec & Jan & February & March & April & Average \\
\hline Temperature & ${ }^{\circ} \mathrm{C}$ & 21 & & & & & 21 & 20.4 & 20 & 20 & 20 & 20 & 21.5 & 20.75 \\
\hline $\mathrm{pH}$ & - & 7.38 & & & & & 7.13 & 7.32 & 6.94 & 7.38 & 6.97 & 7.26 & 6.96 & 7.1675 \\
\hline Electrical conductivity. & $(\mu \mathrm{s} / \mathrm{cm})$ & 1634 & & & & & 1843 & 1678 & 1561 & 1667 & 1537 & 1678 & 1496 & 1636.75 \\
\hline Hardness & ( & 32.64 & & & & & 44.57 & 39.5 & 36.67 & 43.86 & $\mathbf{3 3 . 1}$ & 29.54 & 30.03 & 36.23875 \\
\hline $\begin{array}{l}\text { TAC (Full alkalimetric } \\
\text { tide) }\end{array}$ & (क) & 41.73 & & & & & 47.85 & 42.65 & 36.89 & 31.83 & 30.54 & 39.53 & 38.54 & 38.695 \\
\hline TA (Alkalimetric Tite) & ( $\mathrm{C} F$ & 0 & & & & & 0 & 0 & 0 & 0 & 0 & 0 & 0 & 0 \\
\hline Sulfates & $(\mathrm{mg} / \mathrm{l})$ & 8.74 & & & & & 14.73 & 17.45 & 11.53 & 692 & 8.39 & 7.28 & 6.6 & 10.2425 \\
\hline Chlorides & $(\mathrm{mg} / \mathrm{n})$ & 69.4 & & & & & 111.6 & 88.5 & 98.66 & 76.67 & 66.7 & 69.67 & 54.34 & 79.4425 \\
\hline Calcium & $(\mathrm{mg} / \mathrm{A})$ & 98.43 & & & & & 134.98 & 196.09 & 152.87 & 97.34 & 120.54 & 115.8 & 109.96 & 128.27625 \\
\hline Magnesium & $(\mathrm{mg} / \mathrm{l})$ & 12.13 & & & & & 12.46 & 11.12 & 13.08 & 8.17 & 5.7 & 6 & 10.39 & 6.5875 \\
\hline Sodium & $(\mathrm{mg} / \mathrm{l})$ & 39.01 & & & & & 68.09 & 35.6 & 36.2 & 48.36 & 37.58 & 55.8 & 45.7 & 45.8175 \\
\hline Potassium & $(\mathrm{mg} / \mathrm{n})$ & 22.09 & & & & & 29.89 & 22.7 & 20.89 & 21.78 & 19.35 & 32,8 & 26.78 & 24.535 \\
\hline
\end{tabular}

\section{Source:}

Table 2 The physico-chemical analyses for twelve months for the Source Hamma site.

\begin{tabular}{|c|c|c|c|c|c|c|c|c|c|c|c|c|c|c|}
\hline Parameter & Unit & May & June & Jul & Aug & Sep & Oct & Nov & Dec & Jan & February & March & April & Average \\
\hline Temperatuxe & ${ }^{\circ} \mathrm{C}$ & 42 & 43 & 42.5 & 43 & 42 & 41 & 42 & 43 & 43 & 42 & 41 & 43 & 42.291667 \\
\hline $\mathrm{pH}$ & - & 6.87 & 7.03 & 7.2 & 6.94 & 6.75 & 6.83 & 7.07 & 6.87 & 6.98 & 7.17 & 7.06 & 6.92 & 6.9741667 \\
\hline Electrical conductivity & $(\mu \mathrm{S} / \mathrm{cm})$ & 9234 & 9123 & 10944 & 11956 & 9089 & 9743 & 9078 & 8861 & 8867 & 8837 & 8878 & 8240 & 9404.1667 \\
\hline Hardness. & $(\mathrm{mg} / \mathrm{l})$ & 812.04 & 698.31 & 879.77 & 832.82 & 664.64 & 678.91 & 734.12 & 789.83 & 672.32 & 701 & 638.24 & 651.12 & 729.42667 \\
\hline TAC (Full alkalimetric tifle) & ( $\left.{ }^{\circ} \mathrm{F}\right)$ & 49.45 & 53.09 & 72.13 & 68.05 & 69.12 & 66.83 & 49.5 & 50.64 & 54.86 & 63.1 & 59.02 & 49.03 & 58.735 \\
\hline TA (Alkalimet & ('F) & 37 & 43.78 & 49 & 48.08 & 44.78 & 43 & 39.13 & 30.61 & 31.62 & 41 & 30 & 37.9 & 39.658333 \\
\hline Sulfates & ('F) & 0 & 0 & 0 & 0 & 0 & 0 & 0 & 0 & 0 & 0 & 0 & 0 & 0 \\
\hline Cblorider & (mg /) & 487.33 & 745.76 & 976.82 & 887.6 & 793.65 & 643.94 & 412.47 & 346.71 & 367.6 & 633.89 & 772.88 & 560.89 & 635.795 \\
\hline Calcium & $(\mathrm{mg} /)$ & 876.4 & 1305.87 & 1678.84 & 1789.34 & 1658.8 & 1435.6 & 886.5 & 757.66 & 654.67 & 1105.7 & 1016.67 & 1238.34 & 1200.3658 \\
\hline Mrgessium & (mg /) & 80.4 & 226.7 & 323.5 & 354.6 & 134.5 & 103.76 & 86.54 & 72.6 & 79.65 & 104.25 & 115.8 & 109.96 & 149.355 \\
\hline Sodium & $(\mathrm{mg} / \mathrm{l})$ & 23.4 & 61.52 & 87.67 & 79.56 & 53.06 & 42.4 & 42.5 & 27.67 & 28.67 & 51.7 & 60 & 36.34 & 49.540833 \\
\hline Potassium & $(\mathrm{mg} / \mathrm{l})$ & 377.11 & 945.63 & 1237.87 & 1232.58 & 1028.62 & 728.09 & 345.6 & 376.2 & 278.56 & 557.58 & 735.8 & 615.7 & 704.945 \\
\hline Potassium & $(\mathbf{m g} /)$ & 25.38 & 60.67 & 82.45 & 87.67 & 46.87 & 36.89 & 22.7 & 19.89 & 23.78 & 27.35 & 35.8 & 34.78 & 42.019167 \\
\hline
\end{tabular}

S-aval : 
Study of the Quality of the Thermal Spring Moulay Yacoube Hamma And Its Impact on the Hamma River, Sidi Slimane - Morocco.

Table 3 The physico-chemical analyses for twelve months for the $\mathrm{S}$-aval site

\begin{tabular}{|c|c|c|c|c|c|c|c|c|c|c|c|c|c|c|}
\hline Panmeter & Unit & May & Jane & Jal & Ang & Sep & Oct & Nor & Dex & Jan & Feb & Mar & Apr & Arenge \\
\hline Temperature & ${ }^{\circ} \mathrm{C}$ & 32 & 30 & 32.5 & 33 & 28.5 & 31 & 28 & 32 & 30.5 & 32 & 29 & 32 & 30.875 \\
\hline $\mathrm{pH}$ & - & 6.73 & 7.19 & 6.65 & 6.85 & 6.91 & 7.09 & 7.2 & 6.65 & 6.76 & 7.32 & 6.59 & 6.78 & 6.9205333 \\
\hline Electrical condectivity & $(\mu \mathrm{S} / \mathrm{cm})$ & 5678 & 5453 & 6944 & 7956 & 5059 & 5967 & 5456 & 4597 & 4765 & 4598 & 4923 & 4656 & 5556.8333 \\
\hline Hardness & (mg /) & 49.45 & 33,79 & 52.63 & 45.95 & 49,72 & 46.33 & 29.55 & 30.39 & 34.87 & 4.83 & 39.87 & 33.57 & 41.079167 \\
\hline TAC (Full allcalimetric tite) & (क) & 19.67 & 33.05 & 37.78 & 28.08 & 34.78 & 32.06 & 27.16 & 20.61 & 21.62 & 25 & 20 & 27.34 & 27.265 \\
\hline TA (Alkalimsetric Title) & (P) & 0 & 0 & 0 & 0 & 0 & $\theta$ & 0 & 0 & 0 & 0 & 0 & 0 & 0 \\
\hline Salfate & (क) & 17.53 & 15.36 & 16,83 & 17,76 & 13.05 & 13.34 & 12.57 & 16.13 & 17,62 & 13.09 & 12.83 & 10.34 & 14.754167 \\
\hline Calorides & $(m g / 1)$ & 176.23 & 136.77 & 265.17 & 239.24 & 158.47 & 136.65 & 136.3 & 127.06 & 154.34 & 105.65 & 92.45 & 113.14 & 153.95653 \\
\hline Caldium & $(m g / 1)$ & 89.42 & 226.77 & 263.95 & 284.6 & 164.5 & 133.79 & 86.54 & 132.36 & 104.65 & 78.39 & 95.12 & 39.46 & 145.79583 \\
\hline Afggnesium & (mg / I) & 7.4 & 22.52 & 24.67 & 26.56 & 19.06 & 12.4 & 9.5 & 7.67 & 8.67 & 10.7 & 5.67 & 11.34 & 14.096667 \\
\hline Sedium & (mg / $)$ & 269.01 & 95.63 & 317.77 & 312.86 & 228.61 & 128.73 & 35,76 & 106.02 & 78.06 & 67.23 & 115.8 & 85.27 & 157.5625 \\
\hline Potassien & $(\mathrm{mg} / \mathrm{d})$ & 13.41 & 46.92 & 57.83 & 59.76 & 29.66 & 23.75 & 18.82 & 16.53 & 13.79 & 24.63 & 25.83 & 26.68 & 29.805 \\
\hline Potassium & $(m g /)$ & 32 & 30 & 32.5 & 33 & 28.5 & 31 & 28 & 32 & 30.5 & 32 & 29 & 32 & 30.875 \\
\hline
\end{tabular}

\section{DISCUSSION}

The variation in the contents of different physico-chemical parameters of the water at three sites is represented in the form of histograms, to facilitate comparison between these three sites and also to monitor the evolution of each parameter at these three sites.

\subsection{Temperature}

The temperature values recorded in the downstream wadi are higher than those measured in the upstream wadi. This difference could be explained by the direct discharge of water from the source (whose average temperature is around $42^{\circ} \mathrm{C}$ ) into the downstream site.

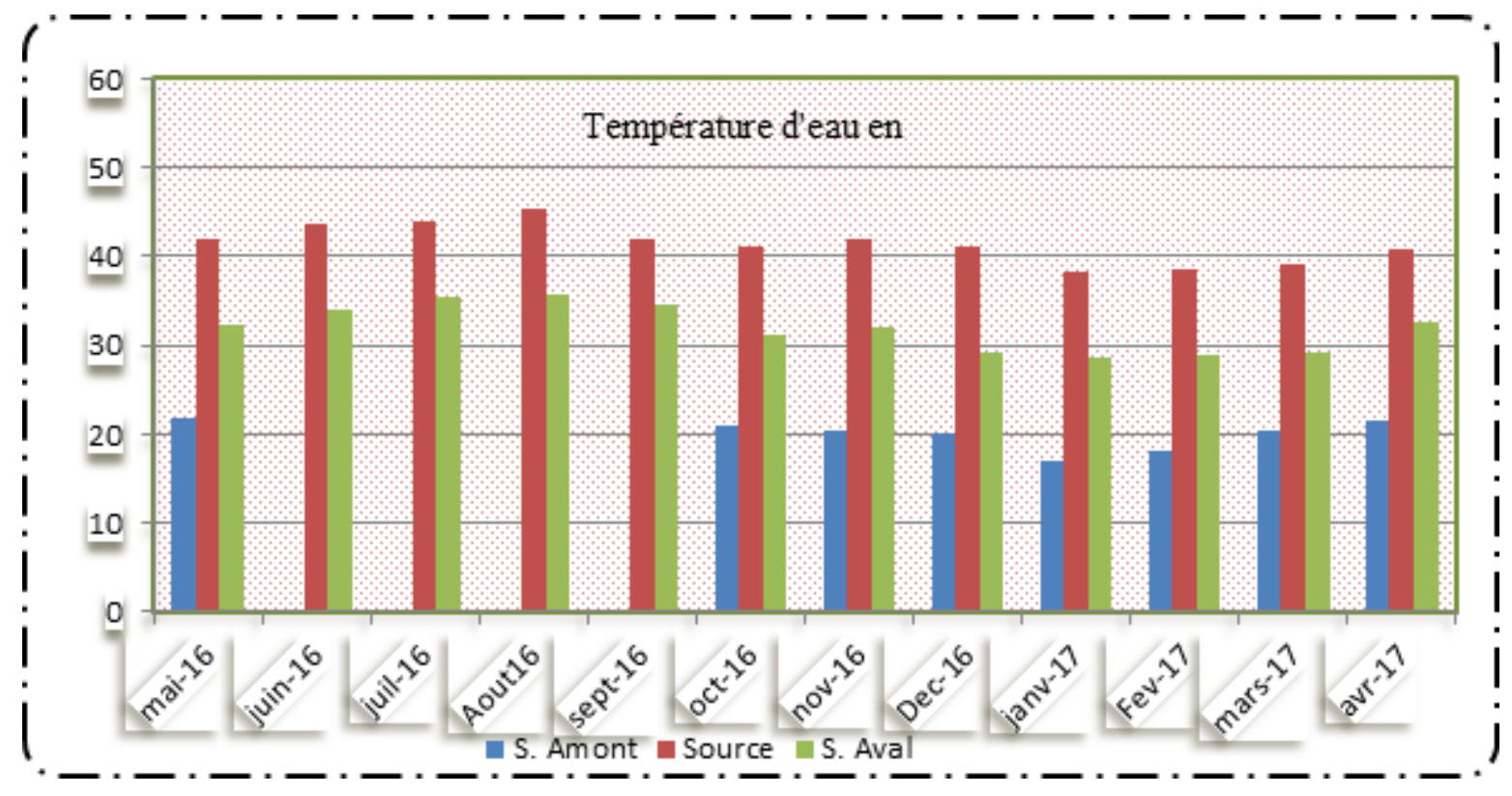

Figure 2: Evolution of water temperature at three sites (May 2016- April 2017). 
Aitsi Salah and Elkhachine Douae, Issati Touria, El Kharrim Khadija, Tayebi Mohammed and Belghyti Driss

\subsection{Hydrogen Potential}

The $\mathrm{pH}$ measured during the study period does not show significant variations between stations. Although this parameter is related to almost all water quality parameters [12] and some authors have mentioned the existence of seasonal fluctuations and/or spatial variations in $\mathrm{pH}$ values in streams $[8,12]$. The average values recorded are almost the same and close to neutrality: 7.42 (upstream), 6.91 (source) and 6.94 (downstream).

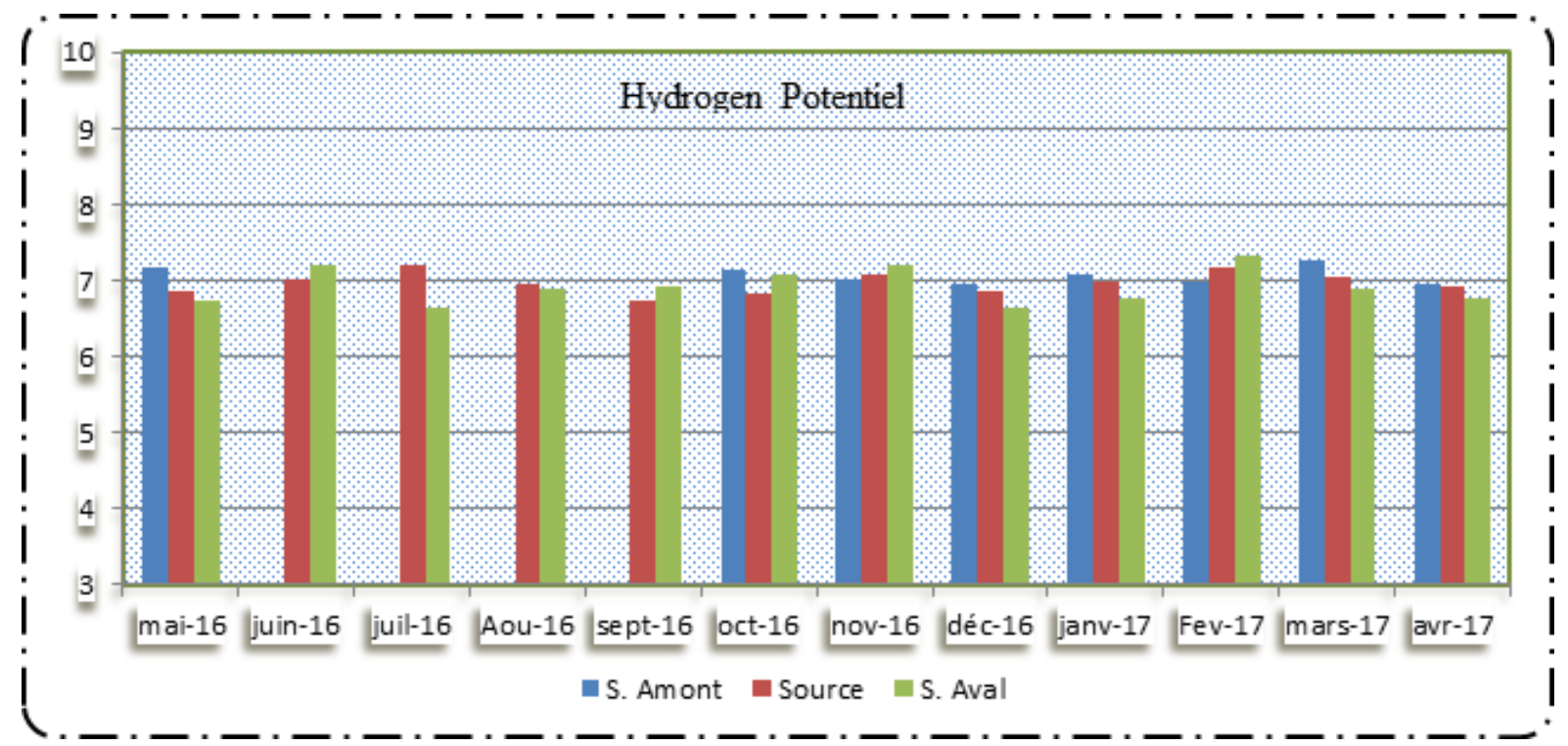

Figure 3: Evolution of water hydrogen potentiel at three sites (May 2016- April 2017).

\subsection{Electrical conductivity}

The conductivity values recorded in the downstream wadi waters are very high compared to those measured in the upstream. These results could be explained on the one hand by the direct discharges from the highly mineralized Hamma Outita source (whose electrical conductivity is between 8730 and $9240 \mu \mathrm{s} / \mathrm{cm}$ ) which increase the conductivity of the water at the downstream site, and on the other hand, during the winter period, by the dilution of the water due to the return of the significant flow of the wadi [13].

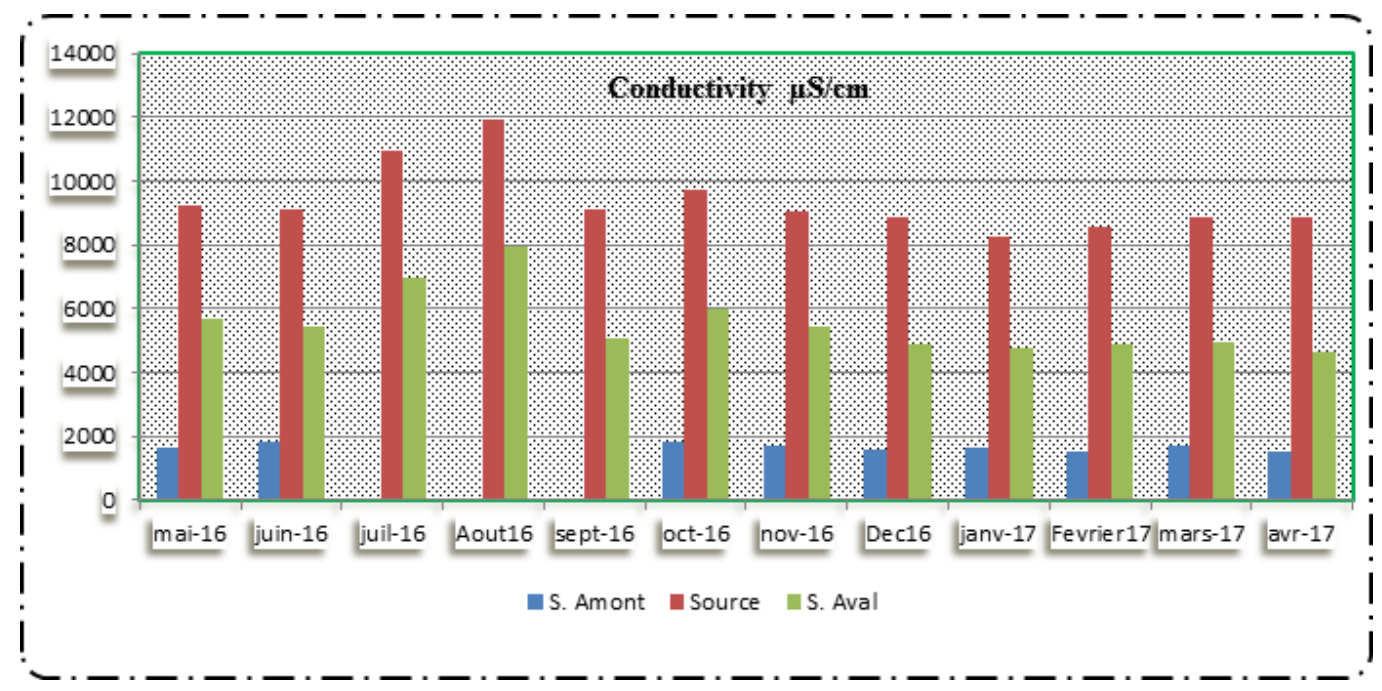

Figure 4: Evolution of water conductivity at three sites (May 2016- April 2017). 
Study of the Quality of the Thermal Spring Moulay Yacoube Hamma And Its Impact on the Hamma River, Sidi Slimane - Morocco.

\subsection{The total hardness}

The total hardness of the downstream wadi waters is high compared to the upstream, and influenced by direct discharge from the thermal spring, which has a significant value of the total hardness, (- upstream: 37.95 /- source: 57.05 /- downstream: 42.62). The hardness of groundwater is generally related to the nature of the sedimentary rocks crossed and is mainly due to the presence of Calcium and Magnesium, soluble constituents of carbonate rocks, especially limestone [14].

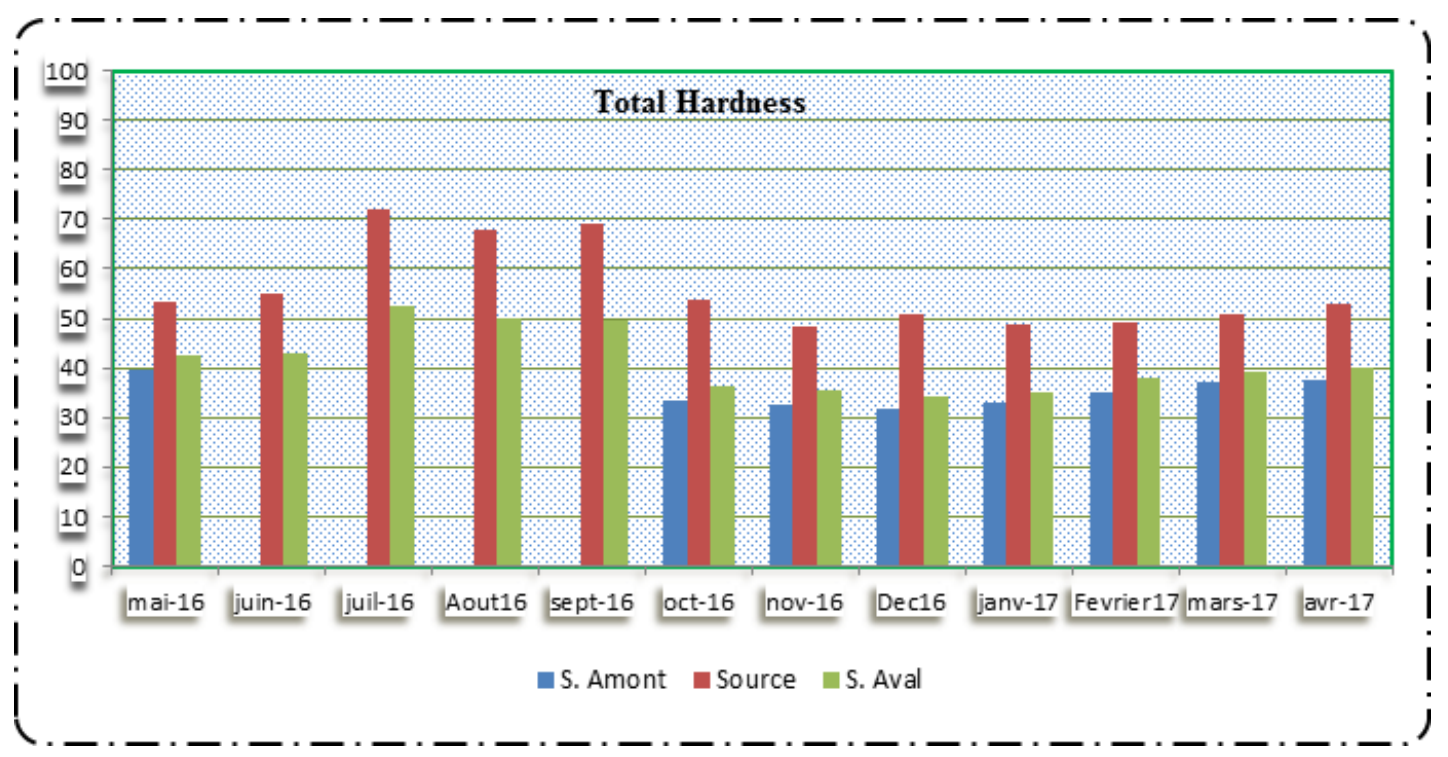

Figure 5: Evolution of water total hardness at three sites (May 2016- April 2017).

\subsection{Sulphates}

For sulphates, the waters of the S-aval site are more charged with these elements than the headwaters. The spring water (more sulphate-laden) discharged into the wadi could explain this difference between upstream and downstream. The average values recorded are in the order of $311.83 \mathrm{mg} / \mathrm{l}$ for $S$-amount waters, $933.39 \mathrm{mg} / \mathrm{l}$ for $\mathrm{S}$-aval and $1130.62 \mathrm{mg} / \mathrm{l}$ for Source waters, reflecting the regional geological nature [10].

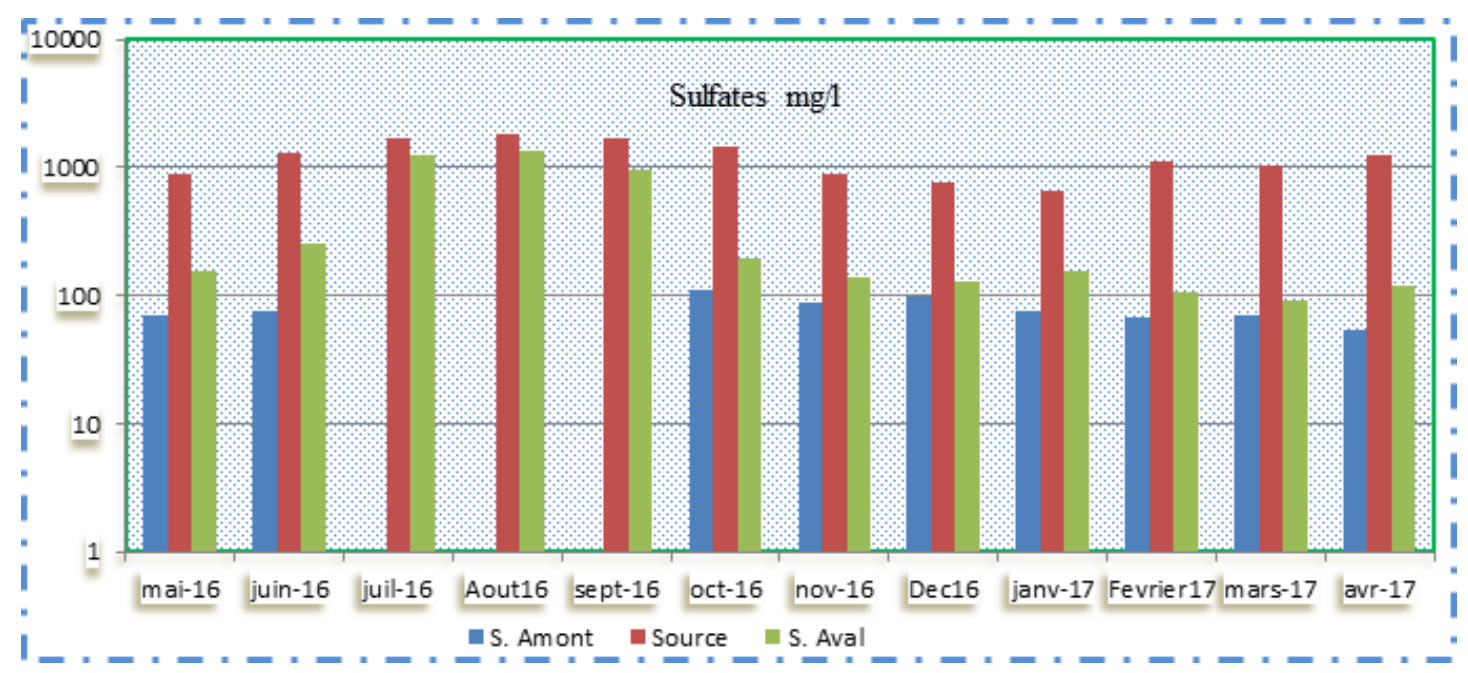

Figure 6: Evolution of water total hardness at three sites (May 2016- April 2017). 
Aitsi Salah and Elkhachine Douae, Issati Touria, El Kharrim Khadija, Tayebi Mohammed and Belghyti Driss

\subsection{Chlorides}

The waters of the wadi are more charged with chlorides and are influenced by the spring waters and by variations in the flow rate of the wadi. The averages recorded for $\mathrm{O}$-amount, Source and $\mathrm{O}$-aval are 254.36, 523.11 and $356.77 \mathrm{mg} \mathrm{cl} \mathrm{-} \mathrm{/1} \mathrm{ions} \mathrm{respectively.} \mathrm{The} \mathrm{evolution} \mathrm{of}$ chlorides over the study period is similar in appearance to that of conductivity. This could be due to the regional geological nature [12] and the nature of the saline rocks at the source [13]

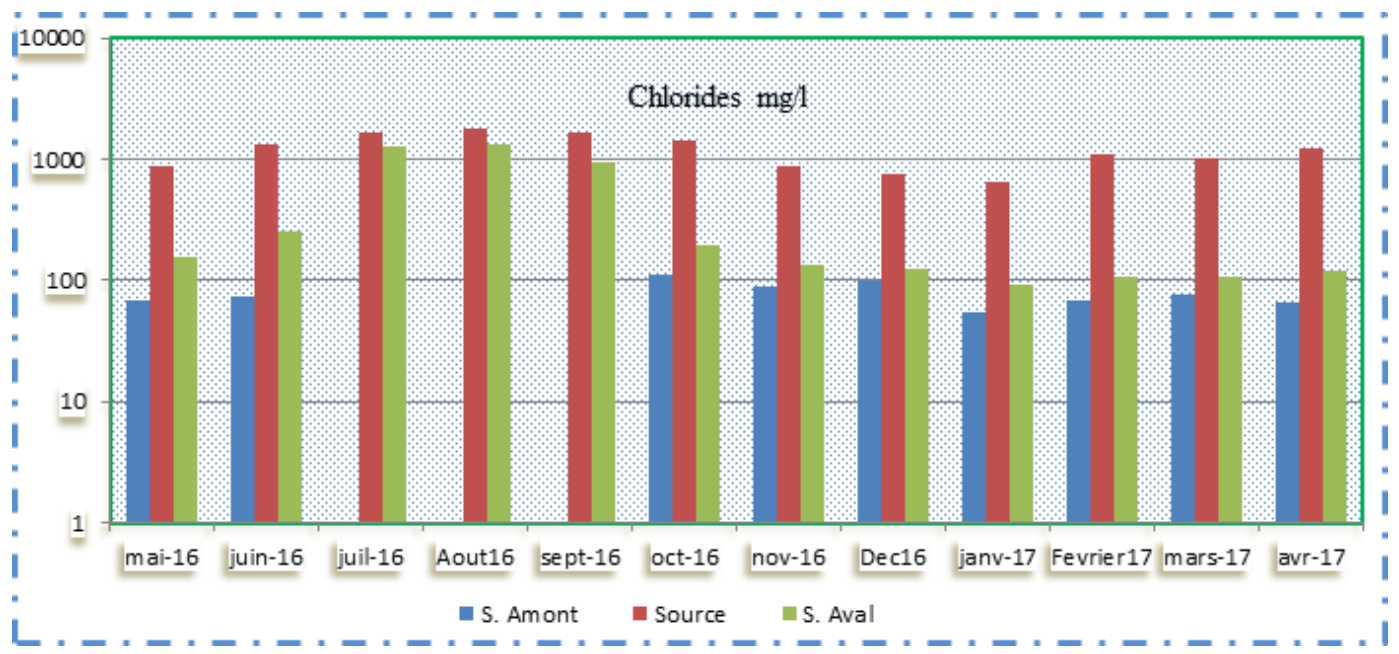

Figure 7: Evolution of water chlorides at three sites (May 2016- April 2017).

\subsection{Calcium}

The concentration obtained upstream of the thermal spring is on average $128.2 \mathrm{mg} / \mathrm{l}$, while the concentration obtained from the thermal spring and its downstream are slightly higher (150 and $135.4 \mathrm{mg} / \mathrm{l})$.

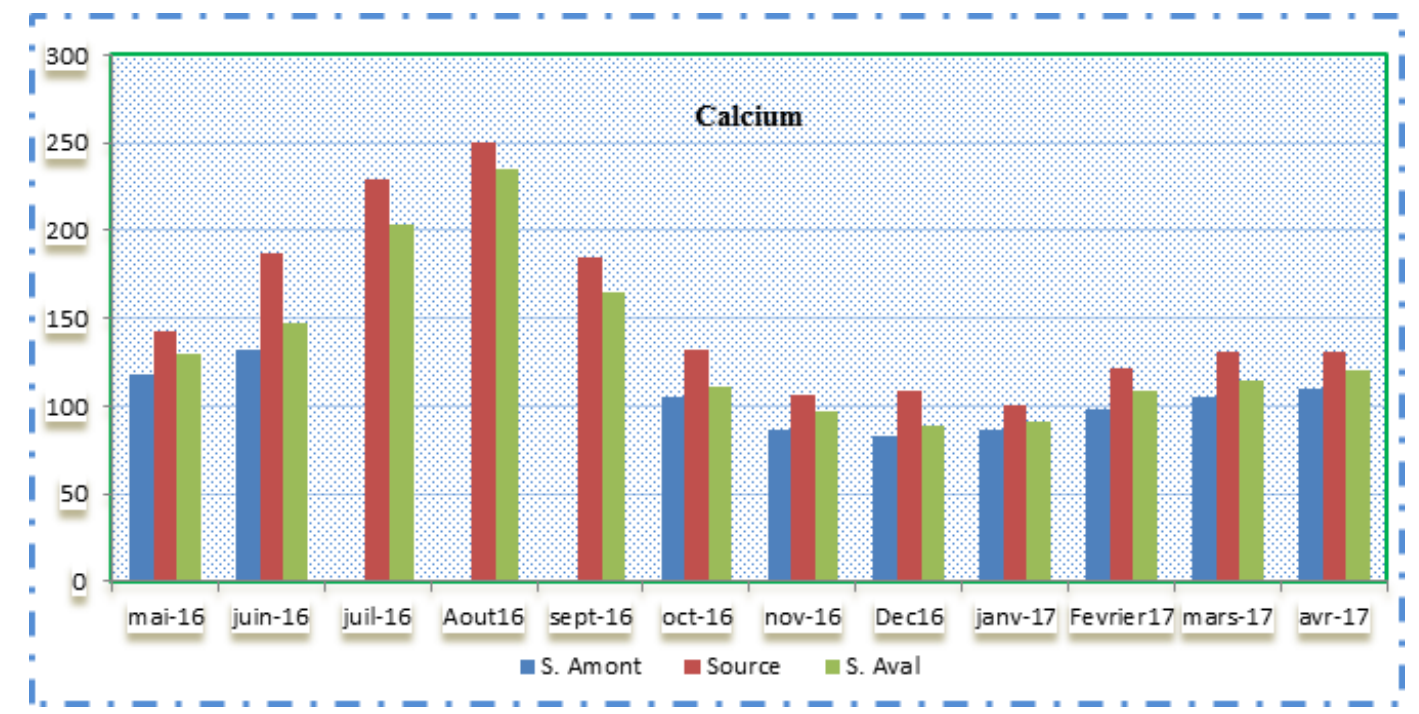

Figure 8: Evolution of water calcium at three sites (May 2016- April 2017). 
Study of the Quality of the Thermal Spring Moulay Yacoube Hamma And Its Impact on the Hamma River, Sidi Slimane - Morocco.

\subsection{Magnesium}

The concentrations of magnesium obtained in the upstream and downstream sites are low compared to that of the thermal spring:

- The two upstream and downstream sites have successive values of $6.34 \mathrm{mg} / \mathrm{l}$ and 13.55 $\mathrm{mg} / \mathrm{l}$.

- Thermal Spring has a high value of $49.34 \mathrm{mg} / 1$.

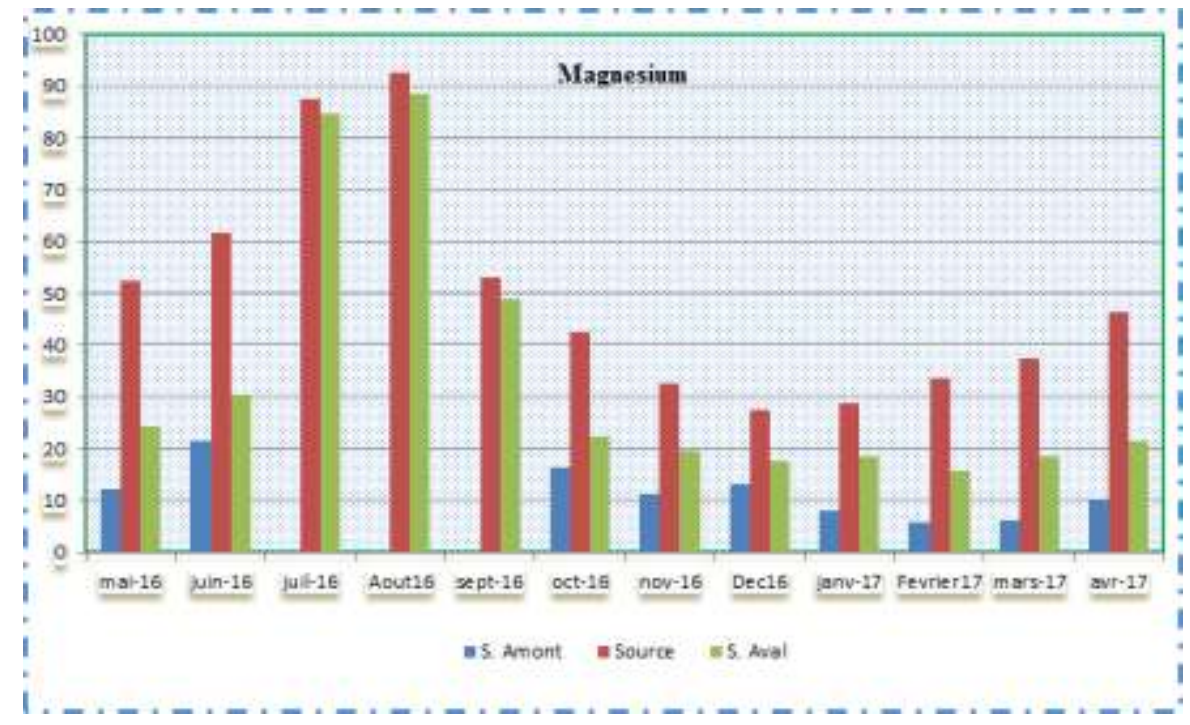

Figure 9: Evolution of water magnesium at three sites (May 2016- April 2017).

\subsection{Sodium}

The sodium value recorded at the upstream site is low and does not exceed $43.28 \mathrm{mg} / \mathrm{l}$, whereas at the downstream site where source Hamma is discharged, the value reached is high at $167.4 \mathrm{mg} / \mathrm{l}$, due to the high mineralization of this source with a high sodium concentration of $713.02 \mathrm{mg} / \mathrm{l}$

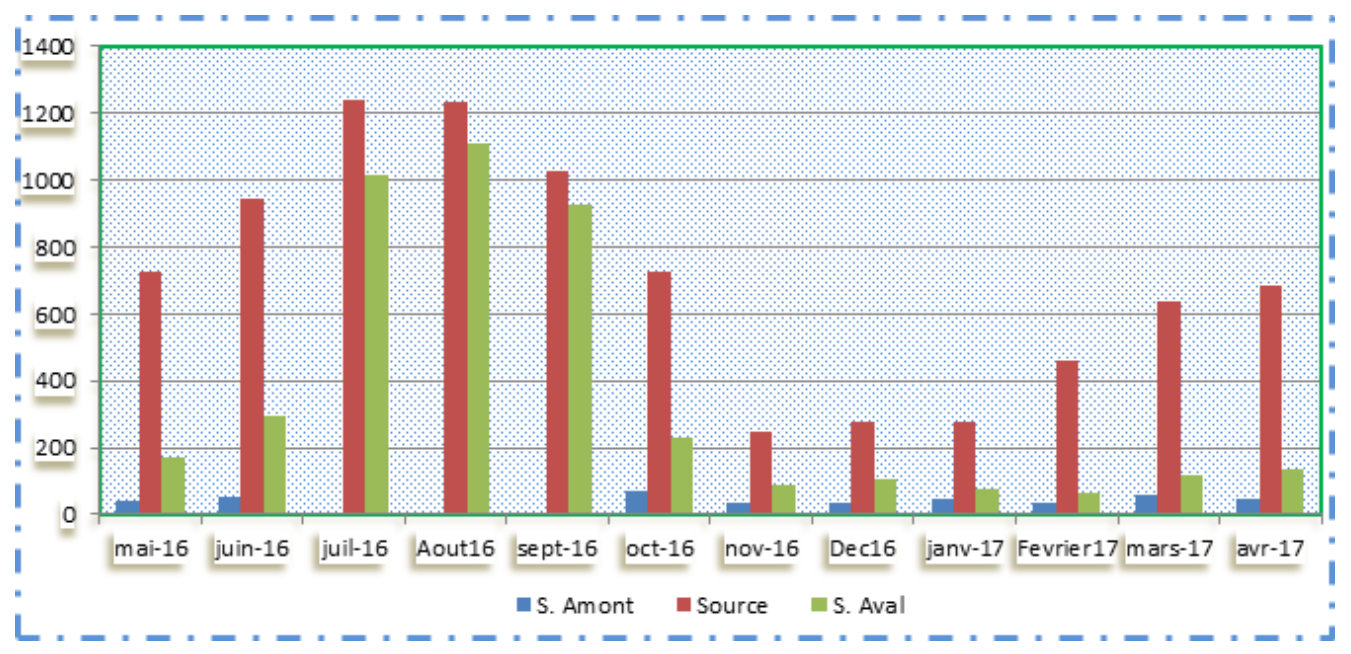

Figure 10: Evolution of water sodium at three sites (May 2016- April 2017). 
Aitsi Salah and Elkhachine Douae, Issati Touria, El Kharrim Khadija, Tayebi Mohammed and Belghyti Driss

\subsection{Potassium}

From the graph obtained, it can be seen that the Hamma Outita thermal spring has an influence on the potassium load of oued by its discharges, because it has a high concentration downstream $(26.71 \mathrm{mg} / \mathrm{l})$ and upstream $(30.13 \mathrm{mg} / \mathrm{l})$, just after its mixing with the source which has a high value in this element $(39.13 \mathrm{mg} / \mathrm{l})$.

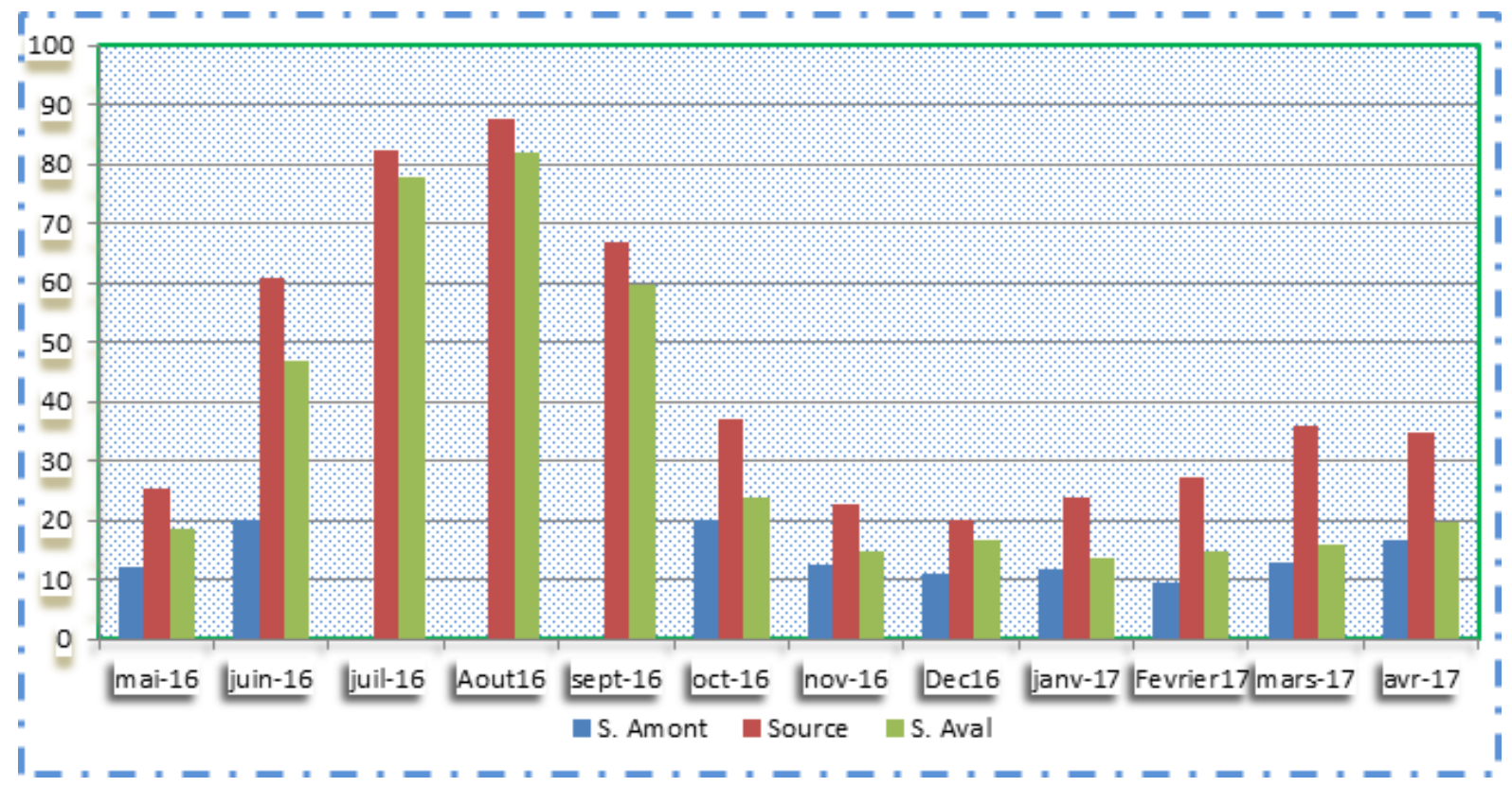

Figure 11: Evolution of water potassium at three sites (May 2016- April 2017).

\section{CONCLUSION}

The results obtained during our study made it possible to meet the objectives set out in the introduction and to draw up a portrait of the physico-chemical and bacteriological quality of the waters of the Ain Hamma Moulay Yacoube spring and those of the section of the Hamma wadi located near the spring.

The waters of the thermal spring are highly mineralized and have very particular physicochemical characteristics. These waters enrich the waters of the Hamma wadi with minerals and modify the physico-chemical quality of the latter, which could have an effect on this aquatic ecosystem downstream.

\section{REFERENCES}

[1] H. EL HAISSOUFI, S. BERRADA, M. MERZOUKI, M. AABOUCH, L. BENNANI, M. BENLEMLIH, M. IDIR, A. ZANIBOU, Y. BENNIS et A. EL OUALI LALAMI. Pollution des eaux de puits de certains quartiers de la ville de Fès, Maroc. Rev. Microbiol. Ind. San et Environn. Vol 5, N 1 (2011) 37-68.

[2] J. El ADDOUli, A. CHAHLAOUI, A. BERRAHOU, A. CHAFI et A. ENNABILI. Qualité physico-chimique et biologique de l'oued Ouislane au sein de la ville de Meknès (centre-nord du Maroc). Revue AFN Maroc. N double 4-5 (2009) 46-58.

[3] S. BRICHA, K. OUNINE, S. OULKHEIR, N. EL HALOUI, et B. ATTARASSI. Étude de la qualité physicochimique et bactériologique de la nappe phréatique M'nasra (Maroc). Afrique SCIENCE 03(3) (2007) 391-404. 
Study of the Quality of the Thermal Spring Moulay Yacoube Hamma And Its Impact on the Hamma River, Sidi Slimane - Morocco.

[4] J. ALIBOU. IMPACTS DES CHANGEMENTS CLIMATIQUES SUR LES RESSOURCES EN EAU ET LES ZONES HUMIDES DU MAROC. Table Ronde Régionale en Méditerranée Athènes, Grèce, Décembre 10-11, (2002) 1-39.

[5] A. CHAHLAOUI, P. CUGNY, S. LEK, A. ZAID et M. RAMDANI. Analyse quantitative de la qualité de l'eau de l'oued Boufekrane (Maroc). Bull. Soc. Hist. Nat. Toulouse, 133 (1997)71-76.

[6] A. ABDALLAOUI. Contribution à l'étude de la pollution des cours d'eau marocains par les métaux lourds : cas de l'oued Boufekrane. Thèse de 3 ème cycle, Université Moulay Ismaïl, Meknès (1990) 258p.

[7] A. CHAHLAOUI. Etude hydrobiologique de l'oued Boufekrane (Meknès), Impact sur l'environnement et la sante. Thèse d'État, Fac. Sci. Meknès. Maroc (1996) 234 pp.

[8] L. KARROUCH and A. CHAHLAOUI. Bio-evaluation of the quality of water of the Boufekrane river (Meknes, Morocco). Biomatec Echo, September, Volume 3, Number 6 (2009) 6-17.

[9] L. KARROUCH et A. CHAHLAOUI. Évaluation de la qualité biologique des eaux de l'oued Boufekrane (Meknès, Maroc).2ème Colloque International sur l'Eau et l'Environnement: Sidi Fredj les 30 et 31janvier (2007) 224-235.

[10] J. EL ADDOULI. Qualité physico-chimique et biologique des eaux polluées réutilisées en agriculture dans la zone puériculture de Meknès (Maroc). Thèse d'état. Fac. Sci. Meknès. (2010) $168 \mathrm{pp}$.

[11] A. ABOULKACEM. Etude hydrobiologique comparative des oueds Boufekrane et Ouislane a la traversée de la ville de Meknès. Impact sur la Sante et l'Environnement. Thèse d’État, Fac. Sci. Meknès. Maroc. (2007)159pp.

[12] J. El ADDOULI, A. CHAHLAOUI, A BERRAHOU, A CHAFI, A. ENNABILI et L. KARROUCH. Influence des eaux usées, utilisées en irrigation, sur la qualité des eaux de l'oued Bouishak- région de Meknès (Centre-Sud du Maroc), Rev. Microbiol. Ind. San et Environn. Vol 3, N¹(2009) 56-75.

[13] L. KARROUCH. Bio-évaluation de la qualité des eaux courantes de la région Meknès (Centre- Sud, Maroc) - Impact sur l'environnement et la sante. Thèse doctorat es sciences en biologie. Fac. Sci. Meknès (2010) 216pp.

[14] A. ABOULKACEM, A. CHAHLAOUI, A. SOULAYMANI, F. RHAZI-FILALI et D. BENALI. Étude comparative de la qualité bactériologique des eaux des oueds Boufekrane et Ouislane à la traversée de la ville de Meknès (Maroc). Rev. Microbiol. Ind. San et Environn. $\mathrm{N}^{\circ} 1$ (2007) 10-22.

[15] A. BEN MOUSSA, A. CHAHLAOUI, R. El Habib. Impact des eaux de la source Ain hamma Moulay Idriss sur la qualité des eaux de l'oued khoumane (Moulay Idriss Zerhoun) Maroc Science Lib, Éditions Mersenne : Volume 3, Nº110704 (2011) 1-17.

[16] A. EZZAÏDI, M. KHALOUFI, M. A. BOUAGOU et M. EL YOUSSI. Un site de tourisme de sante à promouvoir : la station d'Abaynou (province de Guelmim). Le Premier Workshop International sur le Géotourisme et l'Écotourisme dans les régions Souss-MassaDraâ et Guelmim-EsSmara. Mirleft-Guelmim et Assa. Les 8-9 avril (2006). 